On Names in South Asia: Iteration, (Im)propriety and Dissimulation

\title{
Kristapurāna: Translating the Name of God in Early Modern Goa
}

\section{Alexander Henn}

\section{OpenEdition}

\section{Journals}

Electronic version

URL: http://journals.openedition.org/samaj/4038

DOI: $10.4000 /$ samaj.4038

ISSN: 1960-6060

\section{Publisher}

Association pour la recherche sur l'Asie du Sud (ARAS)

Electronic reference

Alexander Henn, « Kristapurāna: Translating the Name of God in Early Modern Goa », South Asia Multidisciplinary Academic Journal [Online], 12 | 2015, Online since 21 October 2015, connection on 10 December 2020. URL : http://journals.openedition.org/samaj/4038 ; DOI : https://doi.org/10.4000/ samaj.4038

This text was automatically generated on 10 December 2020 .

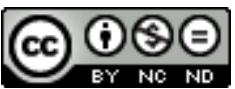

This work is licensed under a Creative Commons Attribution-NonCommercial-NoDerivatives 4.0 International License. 


\title{
Kristapurāna: Translating the Name of God in Early Modern Goa
}

\author{
Alexander Henn
}

Whether or not the name of God is translatable has been a controversial issue for a very long time. ${ }^{1}$ Egyptologist Jan Assmann cites vocabularies found in ancient Mesopotamia that list and translate names of Sumerian, Akkadian, Egyptian, and Hellenistic gods in two, three, and in some cases even four languages. 'During the last three millennia B.C.E. -he summarizes the findings-religion appears to have been a promoter of intercultural translatability. [...] Peoples, cultures, and political systems may be sharply different. But so long as they have a religion and worship some definite and identifiable gods, they are comparable [...] because these gods must necessarily be the same as those worshipped by other peoples under different names' (Assmann 2008: 140-1). Anthropologist Richard Burghart (1989) highlights a comparable insight from the world of Hinduism. Hinduism, he shows, is capable of integrating into its fold a wide range of theological and ritual traditions by attributing to the divine a particular translation-like quality. Brahma, Rama, and other Hindu gods, we learn, manifest themselves in multiple forms, and the Buddha is recognized as an incarnation of Vishnu. The facilitating concept behind this versatility is the idea that the essential nature of the divine is nirguna, formlessness that can manifest and transform itself in any form. The underlying rationales, we can see, are varying. The divine may be seen as the ideal resort of multiple meanings, or the ontic location of no meaning at all. Related presuppositions regarding the conceptualization of religious plurality also differ widely. 'Comparative religion emerged in the West only when various religions could be compared from a non-religious (e.g. humanist) point of view. Indian religion [in contrast] is unique in that various dharmas are [...] compared from a religious point of view [...]' (Burghart 1989: 220). These differentiations notwithstanding, it is a common understanding that the names of gods and, by extension, essential religious expressions are powerful intercultural mediators when they become part of translation or translation-like operations.

2 Intriguingly, however, the opposite statement, which argues that the name of God can never and should never be translated, is equally ancient and ubiquitous. Iamblichus, the 
Syrian Neoplatonic philosopher, and Origen, the Alexandrian Church father, both living in the third century C.E., agreed beyond all differences that there exists an intrinsic sympatheia or mystical link between name and deity that cannot be translated (Assmann 2008: 144). Although indirectly, their positions converge today with those of religious fundamentalists of various origins, for whom the name and essential word of God constitute the untranslatable essence of religious purity or Truth. Again, underlying rationales vary significantly. Political arguments construct religion as a bastion against cultural assimilation, theological reasoning claims the exclusivist knowledge of Truth, semiotic theories discuss symbolic vis-à-vis indexical modalities of 'religious language' (Keane 2004). The point is here not just that the name and word of God is considered untranslatable, or that translation is taken to implicate more than just lexical and sematic mediation. More critical is that the rationale for challenging and refusing the translatability of essential religious expression often lies in the refusal to recognize that there exists more than one religious truth or doctrine around the globe.

What I will do in this paper is scrutinize the ambiguity regarding the translatability of the name and word of God and related questions about the recognition of religious pluralism in a particular post-colonial context. Historically, this context is marked by the earlymodern colonial expansion of Portuguese-Catholic forces into India and Asia, which for Christian Europe led to the encounter with religious cultures that until then were largely unknown. These religious cultures, which at some point in history became globally known as Hinduism, Buddhism and Jainism, occur in the early modern Portuguese sources still under generic and unspecific designations such as gentilismo or, with reference to the Konkan region on India's Western coast, Concanneponni, terms that are distinctly void of any reference to religion and may be translated as 'gentilehood' or 'Konkanness' respectively. The impact of the colonial and religious encounter on Europe was enhanced and complicated by the fact that it coincided with the religious strife of the Protestant Reformation and the sectarian division of Christianity into Catholics and Protestants. This revolutionary upheaval led Christian Europe to an ambivalent and, to some extent, even contradictory attitude vis-à-vis the Gentiles of India and other regions of the world. On the one hand, the Protestant reformation and its Catholic response revived an age-old theological animosity against religious images and led to aggressive accusations and attacks against the gentiles for their alleged 'idolatry' or image worship. ${ }^{2}$ 'Idolater' became a synonym for 'pagan' worldwide in the European Christian sources. On the other hand, the upsetting experience of the sectarian division of Christianity in Europe and the startling encounter with unexpectedly rich religious cultures at the colonial frontier in Asia and the Americas, although gradually and in persistent tension with the alleged 'idolatry' and 'superstition' of the non-Christianized cultures, led in the long dureé to the acknowledgement of religions other than Christianity and a new, pluralistic concept of religion (Stroumsa 2010; Masuzawa 2005).

Geographically, my study is about Goa. Today one of the federal states of India, from 1510 to 1961, Goa was under Portuguese rule and Catholic hegemony constituting, together with other Portuguese enclaves on India's Western coast, the longest-held European colony on Indian soil. Marking an important frontline for the combined PortugueseCatholic expansion into Asia and, for a long time, functioning as the political and religious capitol of the Estado da Índia, ${ }^{3}$ Goa also became a center for the study of Indian languages and the translation of Christian doctrine and mythology into the vernaculars of the potential and actual Indian converts. The initiative for this engagement with Indian 
languages-and translations towards these languages-came above all from Jesuit missionaries and was part of the doctrinal renewal and reassertion of Catholicism vis-àvis the Protestant Reformation. Directives for the linguistic and literary activities in the overseas missions came inter alia from the influential Council of Trent (1545-1563). Next to catechisms, liturgical texts, and confession manuals, one genre of early Indianlanguage translations of Christian topics has gained particular attention today. These are the biblical stories and lives of saints that became known as Christian Purānas, a title that highlights not only the translators' mastery of Konkani and Marathi, the languages spoken at the Western coast of India, and Sanskrit, the classical religious language of Hinduism, but also honors their artful adoption of literary vocabulary and poetic styles derived from the local religious literature of devotional Hinduism or bhakti. ${ }^{4}$

Most highly praised in this regard is the adaptation of the biblical stories into KonkaniMarathi ${ }^{5}$ by the English Jesuit Thomas Stephens (1549-1619). Stephens' work is seen today as the initiating model and masterpiece of the Christian Purāna literature. It was first printed in Goa in 1616 under the title Discuroso sobre a vinda do salvador ao mundo [Treatise on the coming of the redeemer into the world] ${ }^{6}$ em lingoage bramana marastta (sic) [in the Brahmanical Maharashtrian language]. Two other editions followed, in 1649 and 1654. Today the work is popularly known as Kristapurāna. ${ }^{7}$ It exhibits many similarities with the local devotional Hindu bhakti literature. It is structured in two sections called purānas, which relate biblical stories in verse form using the quatrain meter ovi that is characteristic of Maharashtrian bhakti literature. The text includes approximately 4000 stanzas about the Old and 7000 stanzas about the New Testament. Adopting moreover a theological vocabulary that evinces a close affinity with Hindu devotional hymns honoring and worshipping the god Vishnu, Stephens' work is associated today with that of famous Hindu bhakti poet saints and is believed to have stylistically borrowed above all from the work of Śrī Sant Ekanātha (1533-1599), a contemporary of Stephens who lived and worked in Maharashtra (Falcao 2003: 12, Van Skyhawk 1999: 366).

What buttresses the view that Stephens was consciously adopting forms of Hindu literary style and expression is the fact that his work was part of a larger contemporary Jesuit conversion policy that included a strategy known as accommodatio. This strategy propagated the adoption-in fact, the continuation-of certain local customs and cultural expressions in the religious culture and practices of Christian converts at the colonial frontier. It had a famous advocate and practitioner in the Italian Jesuit Roberto Nobili (1577-1657), who tolerated Brahmanical customs such as the wearing of certain body marks and a tuft of hair on the crown of the head and the continuation of particular food habits such as vegetarianism and caste-related purification rituals among Christian converts in the mission of Madurai in South India (Županov 2001). Accommodatio was also practiced in Goa, where the missionaries adopted Hindu ceremonial styles in the annual local church festivals. Especially notable here are the Catholic ceremonies called Zagor. These continued (and to some extent continue to this day) the all-night Jāgar ceremonies that were performed during the annual Hindu temple festivals and that combine religious worship with ludic entertainment, although with one significant intervention: in the songs and plays presented in the church ceremonies, the names, characters, and costumes of Hindu gods are replaced by the names, characters, and costumes of Catholic saints (Henn 2003, 2014). 
7 Not all Christian Purāna texts produced in early modern Goa, however, reveal the same adaptive attitude towards the religious culture of the Indian gentiles. Another Indianlanguage Christian text that I will examine in this article is much more intolerant and repudiative with regard to the gentile culture whose literary styles and expressions it copied. This is the Discursos sobre a vida do Apostolo Sam Pedro [Treatises on the life of the Apostle Saint Peter], to which philologists and historians today commonly refer as Peter Purāna (Tulpule 1979: 382; Priolkar 1967: 18). This work was composed by the French Jesuit Étienne de la Croix (1579-1643). ${ }^{8}$ Printed in Latin script in Goa for the first and only time in 1629, in what was also specified as lingoa Bramana Marasta (sic) (de la Croix 1629: title page), the Peter Purāna shows notable stylistic commonalities with the Kristapurāna. It deals, in good part, with Christian mythology (the life of the Apostle Peter), is structured in three sections called purānas, is composed in the poetic meter of the ovi and it amply borrows in its vocabulary and literary style from Hindu sources, especially the local bhakti literature. In fact, Falcao (2003:13) counts allusions to as many as twenty-six Hindu sources in the Peter Purāna. In one significant point, however, de la Croix' Peter Purāna deviates from Stephens' Kristapurāna: it not only deals with Christian mythology, but also extensively engages in what it calls 'the refutation of the false gods' of the Indian gentiles. In other words, the French Jesuit takes great effort and space to systematically name, list and describe all the gods, saintly persons, and tutelary beings known to him that are worshipped by the gentiles in the Konkan area, addressing thus what-in lieu of the word religion-he calls Concanneponni or 'Konkanness' (de la Croix I.202.9). De la Croix contests and refutes the idea that the gentile deities have any divine nature or sacred value; for him, divinity and Truth are exclusively reserved for the Christian God.

The oddity of a text which thus rejects, in the Hindu context, the theological meaning and appreciation of precisely those Konkani-Marathi terms and expressions that it adopts in order to express the theological truth claim of the Christian god and doctrine in an Indian language is aggravated by other adverse circumstances. The brief but prolific period between the mid-sixteenth and mid-seventeenth centuries during which Catholic missionaries engaged with Indian philology, producing numerous Indian-language vocabularies and grammars and composing the Christian purāna literature, it turns out, was also the period in which the Portuguese-Catholic regime in Goa and other Portuguese-controlled areas in India ${ }^{9}$ launched a ruthless campaign of destruction and oppression against Hindu culture. It was not only that this campaign destroyed with determined iconoclastic violence all Hindu temples, shrines and images throughout Goa and systematically replaced the Hindu monuments with Christian churches, chapels and crosses (Henn 2014). Archaeological findings indicate that some of Goa's oldest churches were also at least partly built from the very rubble of the destroyed temples that they replaced (Mitterwallner 1983; Doshi \& Shirodkar 1983). In addition, the campaign banned and persecuted under severe punishment the public performance of all Hindu ceremonies, including marriage rites and the cremation of the dead. Moreover, Goan historians and literary scholars cite historical sources demonstrating that the missionaries even targeted and destroyed precisely those Hindu books and manuscripts that they themselves used, as sources of learning and stylistic templates, as they produced the Christian purāna literature (Da Cunha Rivara 1858: 14; Priolkar 1967: 76; Patil 1999).

9 Against this background, a second set of problems that I want to address in this article turns around questions regarding the coexistence and contiguity of translation and 
violence, hermeneutics and destruction. Was there a connection between these seemingly contradictory positions? Or were the translations, as the modern division of secular and religious domains implies, merely profane activities that had no intrinsic connection with the religious zealotry in the midst of which they were produced? What does the coexistence of translation and violence imply for the theoretical qualification of translation, and what does it mean for the contemporary concept of religion and the gradually emerging recognition that, next to Christianity, there exist other religions? In pursuing these questions, I will focus primarily on the ways Thomas Stephens and Étienne de la Croix translated and positioned vis-à-vis each other the names and designations of God, gods, and saintly and demonic beings from the two worlds of the Indian gentilismo or Concanneponni and Christian doctrine. Technically, I will rely in my analysis of the Kristapurāna on its modern reproduction by Saldanha (1907) and secondary literature by Nelson Falcao (2003), Hugh Van Skyhawk (1999), and Pär Eliasson (2015), ${ }^{10}$ and for the Peter Purāna on a reading of the original text by de la Croix (1629) supported by its fragmentary translation into Portuguese by Da Cunha Rivara (1865).

Names Translated-Names Negated

Of all the works written in the Christian Purāna style, modern scholars without exception agree that Stephens' Kristapurāna shows the greatest literary skill and poetic art. It summarizes in two purānas the story related in the Bible. The first or Pailo Purana (sic) recounts all the major events described in the old Testament: the creation of the world, the nature of the angels and the fall of Lucifer, the creation of Adam and Eve, their original sin and banishment from paradise, the unfaithful life of people and the great flood, the preservation of Noah, and the call of Abraham. The second or Dusoro Purana (sic) tells the stories and introduces the characters of the New Testament: the birth of Christ the Redeemer; his mother, Mary; John the Baptist; the life and teaching of Christ; his passion, death, resurrection, and ascension to heaven.

11 In presenting the Christian epic, Stephens is noted for creating numerous 'Hindu names' in Konkani-Marathi or Sanskrit in order to designate and circumscribe the Christian God and Trinity, Devabāpa (God the Father), Devasutā (God the Son), and İsphari Santā (the Holy Spirit), as well as Jesus Christ and Holy Mary (Falcao 2003: 41, see also Van Skyhawk 1999: 369). With regard to the biblical story, Stephens thus tells how Devabāpa (God the Father), Vaikunțharāyā (Lord of Heaven), Parameśvara (Supreme God), and Sarvācyā Racanārā (Maker of All) sends Devasutā (God's son), Jeju Kristarāja (Jesus the King), also addressed by the honorific titles of Viśvatāraku (Savior of the World), Jñānadipu Paripurṇā (Lamp of Perfect Knowledge), and Dharmaiticā Denakarū (Sun of Righteousness) to earth in order to defeat Mārūvā (Satan), Devācara (the evil ghost), and Ajāgara (the serpent) and to overwhelm papa (sin), cut off dośa banda (the bonds of guilt), and eradicate avidy $\bar{a}$ (ignorance), thereby bringing dipti (light), jñāna (knowledge), and muktī (liberation) to the people of the world and reconciling svarga and samsāra (heaven and earth; Falcao 2003: 25-34).

12 In a similarly creative and poetic way, Stephens is noted for telling the story of Mary, for whose honorific description and devotional praise he used more than eighty different names and titles, such as Bhāgyevanta Mari (the Blessed Mary), Devamātā (Mother of God), Vaikunțhapatice Māte Ankkuvāri (Virgin Mother of the Lord of Heaven), Pavitra Mātā (Holy Mother), Sadevi Ańkuvāri (Blessed Virgin), Devadutāṇci Rānī (Queen of the Angels), Sadaivi Bhāgeveti Striyāmaji (Most Blessed among Women), Svargīci Rāṇi (Queen of Heaven), and Kṛpe Karūneci (Fountain of Grace and Compassion) glorifying her to be 
candrabimba sundari (beautiful as the moon) and surya nirmala (spotless as the sun) (Falcao 2003: 33-37). It is, among other things, for these skillful and poetic renderings of the name and designation of the Christian holy persons, Jesus Christ and the Holy Mary, in Konkani-Marathi-Sanskrit that Stephens is praised today as 'building bridges between Christian and Hindu worlds' (Falcao 2003: 170) and 'put[ing] Hindu patterns of thought in the service of Christianity' (Van Skyhawk 1999: 365).

13 A critical objection comes from the young Swedish scholar Eliasson (2015), who warns that Stephens' Konkani-Marathi nomenclature for the Christian God may not have been as uncritically adaptive vis-à-vis the local culture as it is commonly assumed. While Stephens, obviously, used many expressions for the divine from the Vaishnavite tradition when translating the designation of the Christian God, Eliasson points out that he never used or even mentioned the name of Vishnu himself. That this notable fact has not been noticed before is arguably due to a modern understanding of translation that makes a distinction between designation and name to the effect that designations can be translated, but names, for their idiosyncratic nature, cannot. A historical comparison, however, suggests that this is a modern assumption, which cannot be found everywhere in ancient contexts. Hence, Assmann presents evidence that in the Greco-EgyptianMesopotamian world it was common that Utu, the name of the Sumerian Sun God, was considered a translation or rendering of Shamas in Akkadian and Shimgi in the Hurritic language, and even had the feminine equivalents Aia in Sumerian and Ejan in Hurritic. ${ }^{11}$ Obviously, no such equivalences were used or even thinkable in early-modern HinduCatholic contexts. To be sure, also in the ancient Mesopotamian context, not every name of god was considered translatable; this, however, Assmann underlines, was for ' theological,' not technical, reasons (Assmann 2008: 140, emphasis in the original). In other words, I think that the avoidance of the name and designation of Vishnu in the Kristapurāna was also based on theological and not technical reasons, and that Eliasson is right when he argues that, 'by giving the God of the Christian religion attributes like 'King of Vaikumțha' [...] but not calling him by the proper name of Viṣnu, [Stephens] implicitly says that it is God (the God of Abraham, Isaac and Jacob) who is King of Vaikumțha,' and not Viṣnu' (Eliasson 2015: 8).

Notably, Falcao himself mentions another, obviously conscious omission of an Indian term in Stephens' Kristapurāna. While commonly using terms like purāṇa, smriti, or śāstra, all of which are designations for genres of religious scripture in the Hindu tradition, the English Jesuit, conspicuously, never uses the term śruti to designate any of the Christian textual corpora (Falcao 2003: 72), although this term represents textual traditions that enjoy the highest theological appreciation and authority in Hindu understanding. More precisely, śruti translates as 'heard' and specifies among other things the oldest Hindu textual corpora of the Vedas, indicating that these were directly revealed from divine origins to human sages and thus in contrast with other textual corpora qualified as smriti, that is, 'remembered,' or purāna, that is, 'ancient,' which are considered to be only of human origin. Arguably, the issue reveals a peculiar concern of the Christian author with regard to Indian-language terms or texts, which do not just symbolically represent what they are dealing with but mark an intrinsic connection with their content, the divine, by evoking what in theological terms is called the praesentia, that is, ritual presence of the divine, and establishing what semiotic theory calls an indexical relationship or physical affinity with it. 
When comparing then Stephens's Kristapurāna with de la Croix' Peter Purāna, both correspondences and deviations become visible. The Peter Purāna reproduces all major stylistic characteristics of the Kristapurāna: it is subdivided into three purānas, deals with a Christian topic, and extensively copies the poetic and literary style of the Maharashtrian Hindu bhakti tradition. The first purāna narrates the story of St. Peter: how he walks among the disciples of Christ; how he attends the last supper; how, after Jesus' capture, he denies out of fear his companionship with him; how he nevertheless is selected to disseminate Christian Law among the Jews. Obviously, the extended narration of Peter's missionary travels and travails among the Jews, also called the 'Gentiles of the Orient,' presented in this first part was meant to stand as a kind of allegory of the challenges and tasks faced by the early modern missionary in the land of the Indian gentiles.

The title of the second purāna then reveals the actual goal of the work, saying: 'Here is dealt with the refutation of the worship of the false gods of the Konkanis' (de la Croix 1629: I.76). This is followed by the presentation of different classes of cuddham devan, 'false gods,' beginning appropriately, although ironically, with the qhonddono or 'refutation' of Gonesso or Ganesh, the god that Hindus invariably venerate as the overcomer of obstacles at the beginning of any significant action (de la Croix 1629: I.102). The first book of the first purāna is then dedicated to the refutations of the worship of 'men, plants and snakes.' Nagues, the god Nageshi, whom Goan Hindus identify inter alia as a snake god, is listed (de la Croix 1629: I.106.), as well as Tulossi, the goddess Tulsi, who is embodied in the sacred Tulasi plant (de la Croix 1629: I.118.12), and Vottam pimpollansso, that is, the sacred peepal tree (ficus religiosa) (de la Croix 1629: I.136). Variously mentioned and condemned is the 'worship of the cow,' as well as the fact that the gentiles refuse to eat beef. Finally, the condemnation of the worship of Santeri Devo, that is, the goddess Sateri, demonstrates an awareness of the significance that this ancient goddess has in Goa and the Konkan, since the text dedicates two entire sections to her in which it is elaborated that she has no divinity but only cuddheponno, 'falsehood,' which is why her worship is of no avail (de la Croix 1629: I.123, 129).

The second book of the second purāna is dedicated to the refutation of purosso, that is, 'ancestors'; addisto, another type of deified human; and Soitana, that is, Satan or the devil (de la Croix 1629: I.153, 156). Here, the individual verses condemn the worship of people who died from suicide, and warn that the devil may disguise himself as ancestor and, with the help of his bhatta (that is, priests) may offer prassada (that is, oracles and other deceptive advice) to people (de la Croix 1629: I.175). The third book of the second purāna, finally, deals with the refutation of the worship of Betalle, that is, the ancient Konkan god Vetal, who is classified as bhüta, a well-known Sanskrit designation for ghosts. Obviously aware of the fact that Goan Hindus often venerate both Vetal and certain bhütas as rakhne, that is, tutelary beings, the book explicitly notes that none of these little gods can be seen as Deva maintra, 'helpers of God,' or as raqhannai, 'guardians' of villages and fields, but all are just forms of Saitana, the devil (de la Croix 1629: I.208, 211). Instead, it is emphasized that only bhoduve, 'angels,' can be seen as 'servants of God' and only the 'prayers of the apostles,' 'relics [of saints],' and 'the sign of the cross' can prevent misfortune and protect people against the devil (de la Croix 1629: I.232, 236).

The refutation of 'false gods' continues in the fourth book of the second purāna, addressing the proverbial 33 million gods of Hindu India, who are simply presented as tetissa cottiche cuddheponno, that is, '33 million [forms of] falseness' (de la Croix 1629: I.279, 295). Finally, the fifth book vilifies the three supreme gods Brahma, Vistnum and Mahessu, 
Brahma, Vishnu and Mahadev (de la Croix 1629: I.1). All these divine beings, which are said to be mentioned in the gentivo gronthi, the scriptures of the gentiles, especially the Vedo and Puranna, are variously highlighted as being neither gods nor representations of the origin of the universe, but weak, ignorant, and unable to offer any salvation. In their stead, the third and final purāna is all set to assert and elaborate that only Poromesvoro, the 'Supreme [Christian] God,' is true, unique, powerful, and without beginning or end (de la Croix 1629: II.1f, see also Ao Leitor [Introduction] 92f).

Translation-Pluralism-Modernity

19 When addressing then the question whether the early modern Christian Purāna literature facilitated the recognition of the Indian gentilismo or Concanneponni as a religion and thus marked the beginning of the recognition of religious pluralism around the globe, an intriguingly polarized image comes to the fore. On the one hand, there can be no doubt that Thomas Stephens was an innovative spirit who revolutionized the communication and understanding between the religious cultures of Christians and Indian gentiles. On the other hand, it is obvious that Étienne de la Croix had a very different impact in this respect. That the Catholic clergy at the time were divided over this question is further illustrated by the fact that the innovative Jesuit strategy of accommodatio, that is, leniency with regard to the continuation of certain local practices among Christian converts in India, led to a major theological dispute. After initially finding the approval of the Roman Curia, the notorious Malabar Rites, as the Jesuit experiments came to be called, met with persistent and vociferous clerical protest during the seventeenth century, and eventually, towards the end of the century, were banned as illegitimate practices facilitating idolatry and superstition (Županov 2001). In the same way, the production and even reading of Christian Purāna literature was banned, and, in 1684, the Portuguese viceroy ordered that henceforth all liturgical texts and official church communications in India had to be either in Portuguese or in Latin (Da Cunha Rivara 1858: 35; Priolkar 1967: 64).

What complicates the question at stake is the fact that modern scholarship tends to obscure the role of the iconoclastic violence in the context and production of the Christian Purāna translations. Most outspoken is Joseph Saldanha, the compiler and editor of the Kristapurāna in 1907. He shows that Thomas Stephens, while being the rector of the Jesuit College in Goa, had to deal with numerous violent incidents. Saldanha publishes a letter that Stephens wrote to his brother, in which he describes a gruesome event that happened 1583 in the village Cuncolim in the province of Salcete, a province that Stephens was overseeing. The letter tells of the destruction and desecration of the local Hindu temple by Portuguese soldiers as well as the subsequent assault upon and killing of five Catholic missionaries by the villagers. Stephens describes the event in some detail, mentioning both the demolishing of the temple and the "[slaying of] a cow upon the altar of the idol so as to clear the place of the superstitious people,' as well as the horrible things that the 'infidels' did to the missionaries, including plucking out eyes, cutting off heads, and 'other acts of atrocity which I am loath to recount' (Stephens 1907: XXXI). Saldanha even quotes Da Cunha Rivara's claim that the Portuguese soldiers 'in the first excitement of the conquest' are said 'to have had all books written in the vernacular language burnt as convicted or suspected of containing the precepts and doctrine of idolatry' (Stephens 1907: XL). Nowhere, though, would he consider that there could have been a connection between the translation of Christian doctrine and the destruction of Indian material culture and literature. A similar position is taken by Hugh Van Skyhawk. He also mentions extensively the 'oppression and atrocities' to which the Portuguese- 
Catholic regime had subjugated the Goan population at the time of Thomas Stephens, yet, not only does Van Skyhawk completely detach the production of the Kristapurāna from this violent environment, but he even insinuates that Stephens' hermeneutical approach marked a distinct renunciation of the violent encounter (Van Skyhawk 1999: 364, passim). Nelson Falcao (2003), who has published the most comprehensive modern analysis of Stephens' Kristapurāna, celebrating it as an early form of 'inculturation,' ${ }^{12}$ does not mention the iconoclastic concomitances of its early modern production at all. ${ }^{13}$

To be sure, the problem is primarily not whether Thomas Stephens can be considered a harbinger of modernity, who was more advanced than Étienne de la Croix. At least, one cannot base such a comparison on the technical and hermeneutical skills involved in the translations, since de la Croix presents, if not the same high quality as Stephens, certainly a translation that marks a remarkable modern innovation for its time. In other words, to say that Stephens was more sympathetic towards the religious culture of the Indian gentiles may identify him as a good man; it does not, however, help us to clarify the question whether or to what extent the novel technique of translating across the sacred scriptures of diverse religions helped to facilitate religious pluralism. Nor is the main question whether one can find an argument justifying the fact that an intense linguistic or philological engagement with a certain culture can, despite all hermeneutical dialogue, go together with an impulse to dominate or even destroy the culture. Such impulses have been amply evidenced and described, referring above all to the theological goal of conversion, that is, the eradication of so-called paganism, or the political goal of conquest and domination, for both of which linguistic knowledge and skill in translation have been shown to be important strategies (Robinson 1993).

What is at stake is the question of how modern scholarship conceptualizes the operations of translation in the context of the early modern Hindu-Catholic encounter and how this conceptualization is positioned with regard to the question of how translation is related to iconoclastic violence on the one hand and the emergence of religious pluralism on the other hand. The significance of this question, I should add, lies in the fact that any uncritical appraisal of the early modern translation of Christian topics into Indian languages runs the risk of mystifying not only translation but also the idea of modernity itself. Obviously, the scholars who deal with Stephens' Kristapurāna take translation to be a transaction that facilitates communication between two different languages. Technically, the most important part of this operation is the functionality of a third or mediating ground, also called tertium comparationis that is conceptualized as intelligibility. This means that a word can be translated from one language to another by virtue of the fact that, arguably, its meaning exists in the lexical and semantic field of both languages. Hence, Konkani bail translates into English woman because both languages have distinct expressions for the common and, in fact, universal notion of female human.

Another essential qualification inherent in this modern conceptualization of translation is revealed by semiotic theory. Translation, it is shown, treats linguistic expressions as symbols. This implies that the sign and the signified are taken to relate to each other by way of an arbitrary cultural code such as language. This symbolic nature of signification excludes or, at least, minimizes the relationship between the symbol and the signified being based on an intrinsic or substantial connection. In other words, the symbol is said not to rely on any specific cultural embodiment and to thus be different from the type of sign that semiotic theory classifies as an icon and that relates to the signified by way of distinct cultural reifications of similarity or similitude. In the same way, the symbol is 
taken to differ from the type of sign classified as an index that is connected with the signified by way of the assumption of specific physical contiguities or affinities. ${ }^{14}$ In fact, following semiotic theory, it is precisely the metaphorical aloofness of the relationship between the symbol and the signified that enables its meaning to break free from any particular cultural embodiment of similarity, contiguity, or affinity and allows it to find expression-that is, translation-in many languages.

The process of translation becomes more complex, though, when its operations are examined in the domain of religion and conditioned by the specific historical context of early-modern Goa. Here, the translation of the Konkani dev (or any other vernacular expression for divine being, for that matter) into the English god, arguably does more than just mediating a common lexical concept for divine being. Rather, the assumption that the name and word of god can be translated into different languages carries with it the assumption that there is more than one religion, and hence acknowledges a pluralistic and relativistic concept of religion. More precisely, I argue that the scholars praising Stephens' Kristapurāna as a remarkable piece of modern translation implicitly take for granted that the producers of the Christian Purāna literature operated under the modern philosophical presupposition that Religion marks an anthropological universal, whose cultural diversification into many religions can be mediated by the same principle that mediates between different linguistic expressions in translation.

The crucial nature of this modern assumption can hardly be exaggerated in the historical contexts of the Catholic-Protestant division in Europe and the Christian encounter with the religious cultures of Asia and America in the sixteenth and seventeenth centuries. In particular, the revival and intensification of the theological debate about so-called idolatry initiated a global attack against the use of religious images (Bernand \& Gruzinski 1988, Henn 2014) that also challenged and complicated the idea that the Christian Truth can be translated or Christian prayer formulated in 'pagan languages' (Keane 2007). To be sure, both the repudiation of religious images and the questioning of the translatability of religious language existed long before and were based on a multitude of theological, moral, and aesthetic arguments. The point to be highlighted is therefore that, in the transition from the pre-modern to the modern period, the problem with images and translation acquired an entirely new and global dimension, which Webb Keane (2007: 59) calls a shift in 'semiotic ideology' and which Michel Foucault elaborates in his Les Mots et Les Choses (1973). This shift involved nothing less than a fundamental upheaval of the ways in which the 'Truth,' or knowledge for that matter, can be accessed and communicated. Moreover, it is questioned today whether the modern paradigm that correlates the philosophically argued singular of Religion with the ethnographically experienced plural of religions indeed had the liberalizing and relativizing effect that is ascribed to it (Stroumsa 2010), or whether it rather obscures a hidden Judeo-Christian notion of transcendence or even monotheism (Bell 2003, De Vries 2008, Masuzawa 2005, Henn 2014). It is against this background that one must problematize the assumption that translation and signification mark neutral and universal operations that can be detached from the historical contexts and cultural conditions of their production or practice. Burghart's analysis (1989) of the ability to render different religious traditions translatable in the Hindu context by reference to the notion of an unqualifiable and, therefore, all-embracing and potentially polytheistic nature of the divine marks a notable example of a mode of translation that operates on a paradigm that differs from the concept of semantic intelligibility. Revealing the deictic nature of the notion of God used 
by the Nuer in Sudan, Michael Lambek provides another interesting example (Lambek 2008). Similarly, I argue that the early modern missionary translations in Goa did not treat their subjects, the name of god and the various notions of divine agency, simply and exclusively by reference to semantic intelligibility or arbitrary symbols, but rather saw them invested with semiotic power and theological efficacy, the mediation and control of which required more than just semantic operations.

In order to substantiate this argument, I would like to return once again to de la Croix' Peter Purāna. Arguably, the most striking feature of this text is how conceptually similar and theoretically inherent to the Christian Self is the gentile Other that the text constructs and presents. Nothing of the Concanneponni, it seems, is really different or altogether new to the Christian author; all is just in reverse order, like the Devil and the false gods that hold the place of the True God, or has its opposite equivalents, like the gentile scriptures of the Vedas, purānas and śāstras that occupy the site of the Christian Law. In the same way, Vetal, the bhütas and demons are said to just deceptively pretend to do what their Christian equivalents, the angels, apostles and other servants of god do in fact, and the many useless and powerless practices and objects of the gentiles are said to prevent them from recognizing the power that emanates from Christian practices and objects such as the prayers of the apostles, the relics of the saints, and the sign of the cross.

Intriguingly, the Concanneponni and the Christian doctrine, although positioned as opposites and adversaries, are thus not presented as radically different and separate. Unlike later periods of Orientalism, the colonial subject is not portrayed as the polarized and distanced Other, but rather appears as a distorted or decayed form of the Self. Most revealing here is a passage in the Peter Purāna in which the relationship between Concanneponni and Christian doctrine is expressed allegorically by saying: 'when gold is mixed with an alloy [of inferior material], the venerable name of the gold is also claimed by the alloy.' Obviously associating gold with the God of the Christian tradition and equating the alloy with the demonic forces of the Concanneponni, the text goes on to say that, therefore, only 'the force of fire that separates the gold from the alloy' is able to rescue the 'light' of the Christian truth from the 'darkness' of the Concanneponni (de la Croix 1629: I.202.11f).

In sum, what the passage reveals is that translation in the Peter Purāna operates on the assumption of a distinct affinity between Concanneponni and Christian doctrine, implying that 'Christian Truth' is pervasive, that is, known and present throughout time and space, except for those areas where it is misconceived, corrupted and obscured by the ignorance of the cega gentilidade 'blind gentilehood' (de la Croix 1629: I, Ao Leitor [Introduction] 92) and the deceptive fabrications of the Devil. ${ }^{15}$ Therefore, it does not stretch interpretation too much to argue that the reference that the allegory of 'the gold and the alloy' makes to the 'force of fire'-as rectifying the allegedly deceptive use of the true name of the Christian God and restoring the corrupted and obscured Truth of Christian doctrine in the pagan world-reveals that the contemporaneity of the production of the Christian Purāna literature and the destruction of the material culture and literature of Indian gentiles was by no means a coincidence. Rather, we recognize that Christian Purāna literature was consciously and strategically meant to replace Hindu bhakti literature, just as Catholic churches and chapels replaced Hindu temples and shrines.

Conclusion 
By way of conclusion it is to be acknowledged that the early modern missionary translations of Christian mythology and doctrine into Indian languages and the rendering of designations and honorific titles for the Christian God, Jesus Christ, and the Holy Mary into designations adopted and borrowed from the theological and devotional repertoire of Hindu literature initiated innovative methods and perspectives in the communication and understanding between the religious cultures of the Indian gentiles and the European Christians. At the same time, however, the materials from Goa reveal that the translatability of the name of the Christian God still had clear theological limitations at the turn of the sixteenth and seventeenth centuries. These limitations were due not only to the denial of the divine status and nature of the gods of the Indian gentiles, but also to the fact that Christian authors were far from recognizing that the so-called gentilismo or Concanneponni constituted a religion and thus evidenced the existence of religious pluralism around the world. Instead, this study has shown that the early modern production of Indian-language Christian texts in greater Goa was an intrinsic part of a strategic campaign of destruction, oppression, and replacement directed against Indian and Hindu culture and literature.

The critical finding of the study is that relevant modern scholarship tends to obscure this connection between the literary activities of the missionaries and iconoclastic destruction, thereby revealing a problematic perspective on the concepts of translation and religious pluralism. The failure to recognize the connection between translation and violence, hermeneutics and destruction, it becomes clear, is not based on historical ignorance or factual denial, but on epistemic assumptions. Even where the contiguity of translation and violence is seen and recognized, it is denied that there exists any relevant connection between the two. The reasoning for this lies in the implicit assumption that translation operates on a neutral ground of intelligibility that not only is detached from any concrete and embodied expressivity of the cultures that it mediates, but also has no relevant connection with the contingencies that determine its political rationale and historical production. Obviously suppressed is the anthropological insight into the historically changing and culturally diverse significance that words and other forms of spoken or written expression and communication, including translation itself, have beyond and apart from their lexical meaning and semantic intelligibility (Burghart 1989, Rafael 1983, Keane 2004, 2007). Arguably, this mystification of the historical condition and cultural embodiment of language and translation extends to the mystification of the modern emergence of religious pluralism itself. The argued natural affinity of translation and pluralism, we have seen, tends to obscure the theological denial, iconoclastic destruction, and semiotic misrepresentation that the translation of the name of the Christian God has brought to many languages and religions of the world.

\section{BIBLIOGRAPHY}

Asad, Talal (2003) Formations of the Secular: Christianity, Islam, Modernity, Stanford: Stanford University Press. 
Assmann, Jan (2008) 'Translating Gods: Religion as a Factor of Cultural (Un)Translatability', in Hent De Vries (ed.), Religion: Beyond a Concept, New York: Fordham University Press, pp. 139-49.

Barreto Xavier, Ángela; Županov, Ines (2015) 'Portuguese Linguistic Empire: Translation and Conversion', in Catholic Orientalism: Portuguese Empire, Indian Knowledge (16th-18th Centuries), Oxford: Oxford University Press, pp. 202-44.

Bell, Catherine (2002) 'The Chinese Believe in Spirits: Belief and Believing in the Study of Religion', in Nancy Frankenberry (ed.), Radical Interpretation in Religion, New York: Cambridge University Press, pp. 100-17.

Bernand, Carmen; Gruzinski, Serge (1988) De L'Idolâtrie: Une Archéologie des Sciences Religieuses, Paris: Éditions du Seuil.

Burghart, Richard (1989) 'Something Lost, Something Gained: Translations of Hinduism', in Günther-Dietz Sontheimer \& Hermann Kulke (eds.), Hinduism Reconsidered, Delhi: Manohar, pp. 213-25.

Chakravarti, Ananya (forthcoming) ‘Between Bhakti and Pietà: Untangling Emotion in Mārāțhī', in History of Religions.

Da Cunha Rivara, Joaquim H. (1858) Ensaio Historico Da Língua Concani, Nova Goa: Imprensa Nacional.

De la Croix, Esteuaõ [Étienne] (1629) Discursos Sobre A Vida Do Apostolo Sam Pedro, microfilm series 198 and 199, Biblioteca Nacional de Portugal, Lisbon.

De Vries, Hent (2008) ‘Why Still “Religion”?', in Hent De Vries (ed.), Religion: Beyond a Concept, New York: Fordham Press, pp. 1-100.

Doshi, Saryu (ed.) (1983) Goa: Cultural Patterns, Bombay: Marg Publication.

Eire, Carlos (1986) War Against the Idols: The Reformation of Worship from Erasmus to Calvin, New York: Cambridge University Press.

Eliasson, Pär (2015) On the Edge: A Minor Study of the Concept of Mokșa in the Christian Purāna of Thomas Stephens, unpublished manuscript, University of Göteborg.

Falcao, Nelson (2003) Kristapurāna: A Christian-Hindu Encounter. A Study of Inculturation in the Kristapurāna of Thomas Stephens, S.J. (1549-1619), Anand: Gujarat Sahitya Prakash.

Foucault, Michel (1973) The Order of Things: An Archaeology of the Human Sciences. New York: Vintage Books.

Godinho, Manuel (1990 [1655]) Intrepid Itinerant: Manuel Godinho and His Journey from India to Portugal in 1663, John Correia-Affonso (ed.), V. Lobo \& J. Correia-Affonso (trans.), Bombay: Oxford University Press.

Henn, Alexander (2014) Hindu-Catholic Encounter in Goa: Religion, Colonialism, Modernity, Bloomington: University of Indiana Press.

Henn, Alexander (2002) Wachheit der Wesen: Politik, Ritual und Kunst der Akkulturation in Goa, Münster: LIT.

Keane, Webb (2004) 'Language and Religion', in Alessandro Duranti (ed.), A Companion to Linguistic Anthropology, Malden: Blackwell, pp. 431-48.

Keane, Webb (2007) Christian Moderns: Freedom and Fetish in Mission Encounter, Berkeley: University of California Press. 
Lambek, Michael (2008) 'Provincializing God? Provocations from an Anthropology of Religion', in Hent De Vries, Religion: Beyond a Concept, New York: Fordham University Press, pp. 120-38.

Masuzawa, Tomoko (2005) The Invention of World Religions, or, How European Universalism was Preserved in the Language of Pluralism, Chicago: University of Chicago Press.

Mitterwallner, Gritli von (1983) ‘Testimonials of Heroism. Memorial Stones and Structures', in: Saryu Doshi (ed.), Goa: Cultural Patterns, Bombay: Marg Publication, pp. 41-49.

Patil, Anand (1999) 'Literatures in Portuguese Colonial Goa: The Battle of Puranas', Govapuri: Bulletin of the Institute Menezes BraganzaI, 1(3): pp. 56-84.

Pearson, M.N. (1967) The Portuguese in India, Cambridge: Cambridge University Press.

Pearson, M.N. (2005) ‘The Search for the Similar: Early Contacts between Portuguese and Indians', in The World of the Indian Ocean 1500-1800: Studies in Economic, Social and Cultural History, Aldershot: Ashgate, pp. 144-59.

Priolkar, Anant Kakba (1967) Goa Rediscovered, Bombay: n.p.

Rafael, Vicente (1988) Contracting Colonialism: Translation and Christian Conversion in Tagalog Society Under Early Spanish Rule, Ithaca: Cornell University Press.

Robinson, Rowena (1993) 'Some Neglected Aspects of the Conversion of Goa: A Socio-Historical Perspective', Sociological Bulletin, 42 [182], pp. 65-83.

Stephens, Thomas (1907 [1616]) The Christian Puranna of Father Thomas Stephens of the Society of Jesus, Joseph L. Saldanha (ed.), Mangalore: Simon Alvares.

Stroumsa, Guy (2010) A New Science: The Discovery of Religion in the Age of Reason, Cambridge (Massachusetts): Harvard University Press.

Subrahmanyam, Sanjay (2001) Penumbral Visions: Making Politics in Early Modern South India, Oxford: Oxford University Press.

Tulpule, Shankar G. (1979) Classical Marathi Literature, Wiesbaden: Otto Harrassowitz Van Skyhawk, Hugh (1999) “....in this bushy land of Salsette...”: Father Thomas Stephens and the Kristapurāna', in A. Entwistle, C. Salomon, H. Pauweis, M. Shapiro (eds.), Studies in Early Modern Indo-Aryan Languages, Literature and Culture, Delhi: Manohar, pp. 363-78.

Županov, Ines (2001) Disputed Mission: Jesuit Experiments and Brahmanical Knowledge in Seventeenthcentury India, Delhi: Oxford University Press.

\section{NOTES}

1. I would like to thank Ines Županov for her valuable comments on an earlier version of this article; I thank Anne Feldhaus for discussing this latest version with me and helping me refine the English.

2. Interestingly, the climax of the iconoclastic destruction that was triggered by the revival of this theological controversy over religious images happened in three parts of the world in the same period, between 1540 and 1560, targeting Catholic images in Central Europe (Eire 1986), Hindu images in Western India (Henn 2014), and Nahua or Aztec images in Mexico (Bernand \& Gruzinski 1988). This shows that the early modern revival of the theological antagonism toward images gained a truly global dimension in the mid-sixteenth century. 
3. The political framework of the combined Portuguese-Catholic regime that constituted the Estado da Índia, the Portuguese empire in Asia, was the padroado, that is, political patronage and supervision of all overseas missionary activities by the Portuguese Crown.

4. Literally translated as 'participation,' bhakti characterizes a form of piety that favors an intimate relationship with a personalized god and, to some extent, constitutes a demotic counter-current to certain aspects of Brahmanical theology and temple religiosity. In the field of literature, bhakti religiosity helped to boost regional languages against the claimed exclusivity of Sanskrit in religious writings, stimulating the production of a rich body of devotional literature in the various regional vernaculars. In Maharashtra, bhakti literature has especially deep historical roots, going back to famous poet-saints such as Jñāneśvara (c. 1275-96), and experienced a second heyday at the time and in the work of Ekanāth (1533-1599).

5. The question whether the language of the Kristapurāna, which the Imprimatur of 1616 describes as bramana marrasta (sic) (Stephens 1907: LXXXVII), is to be classified as 'Old Marathi' (Skyhawk 1999: 363) or a 'Konkan form of Marathi' or 'downright Konkani' (Stephens 1907: LXVII, LXVI), has long been a matter of dispute among scholars and activists involved in Konkan language politics. Most scholars today seem to concur with Saldanha's position that, given the language dynamics in the early-modern Konkan region, the question cannot be clearly decided and that the Kristapurāna was obviously intelligible both to people who then lived in areas which are today Konkani-speaking and to people in areas which are today Marathi-speaking. I have therefore decided to call the language of the historical Kristapurāna Konkani-Marathi.

6. Unfortunately, no original or early copy of this text is extant today. Instead, Stephens' Kristapurāna exists in two printed reproductions. One of them, in Devānāgari script, is based on a handwritten manuscript found in 1925 in the Marsden Collection of the School of Oriental Studies archives in London. It is not known who made this reproduction or when and where it was made. Schurhammer speculates that it may have originated in the eighteenth century (Falcao 2003: 42). Another reproduction, in Latin script, was compiled and edited by Joseph L. Saldanha in 1907 in Mangalore from numerous handwritten manuscripts that were and possibly still are in liturgical use among the Goan diaspora population in South Kanara. Comparing the two reproductions, Falcao notes that the Marsden manuscript uses 'terms and concepts that are more Sanskritized and Indianized' (Falcao 2003: 23). In 1956 and 1996, modern editions in Devānāgari appeared in Pune and Mumbai, respectively.

7. It is not entirely clear whether, and if so when, Kristapurāna became the title of one of the historical editions. The imprimaturs or licenses for printing the first edition, issued in 1614/1615, mention only the Portuguese title of the Discursos. In some of the licenses for the second edition, issued in 1646/1647/1649, the title of the work reads rather as descriptive or abbreviated such as: este livro da Purana or Purana do Padre Thomaz Estevão [this book of Purāṇa; Purāṇa by Father Thomas Stephens]. In the licenses for the third edition, issued in 1653/1654, the title is then given as Puranna da vinda e vida do Christo [Purāna of the coming and life of Christ] (Stephens 1907: LXXXVII-LXXXIX). Falcao cites the title of the Marsden edition in London as 'The Christian Purāna' (Falcao 2003: 213). It may be that the title Kristapurāna first appears in one of the modern reproductions.

8. It is preserved today in two microfilm series (198 and 199) in the Biblioteca Nacional de Portugal in Lisbon. A substantial fragment of de la Croix' Peter Purāna was found by the Goan historian Da Cunha Rivara in the Biblioteca Publica de Nova Goa (Panjim) in the mid-nineteenth century. Using a slightly modernized transliteration, Da Cunha Rivara reproduced and printed this fragment and translated it into Portuguese in his Ensaio Histórico da Língua Concani (1858: 131ff).

9. The Portuguese-controlled regions of Baçaim, Bombay, Damão and Chaul in today's Maharashtra and Gujarat and the region of Mylapur in Tamil Nadu were also affected by the violence. Arguably, the South of India, in particular Tamilnadu (except the Mylapur region) and 
Kerala, where the Jesuits were also active, was spared from major iconoclastic violence, because the Portuguese-Catholic regime had no major military presence there.

10. Ananya Chakravarti's forthcoming article on the Kristapurāna in History of Religions was not yet accessible to me at the time this went to press.

11. Obviously, many more examples of the translatability of names can be found. A particularly appropriate example might be the first name of the author of the Peter Purāna, which in its original French version is Étienne and on the title page of the Peter Purāna appears in its Portuguese rendering [E]steuaõ (de la Croix 1629, title page).

12. 'Inculturation' is the term used by the Roman Catholic Church referring to the adaptation of local cultural customs, e.g. the veneration of ancestors in China, in the teachings and practices of local churches.

13. Ângela Barreto Xavier and Ines Županov mention the violence only in passing in their chapter on Portuguese Linguistic Empire: Translation and Conversion (2015). This may have to do with the fact that they focus primarily on South India and other places where the Portuguese-Catholic regime could not engage in iconoclastic violence because it had a much weaker military presence than in Goa and on the western coast. Subrahmanyam (2001) demonstrates, for instance, that the famous Tirumale-Tirupati temple complex in Andhra Pradesh was targeted for destruction by the Portuguese; however, the plan was not executed because of the military superiority of the Hindu kingdom, Vijayanagara, that was ruling in the region.

14. The conceptualization of this tri-partite division of semiotic signs goes back to the work of Charles Sanders Peirce. Its general meaning for the study of culture is elaborated in language philosophy (Jakobson 1965); its relevance for the study of the history and anthropology of religion has been discussed by Webb Keane $(2004,2007)$.

15. To elaborate on the full dimension and significance this paradigm of similarity had in the early-modern Portuguese-Indian encounter would exceed the space of this article. As I show in more detail elsewhere (Henn 2014), the pervasive 'search for the similar'-as Michael Pearson cogently called the phenomenon (1987: 116; 2005)-manifested itself in Portuguese chronicles and missionary corpora in numerous and long-lasting speculations about hidden theological commonalities, linguistic similarities, and genealogical relationships between Indian gentiles and European Christians. Its most curious instance might have been Vasco Da Gama's error after his celebrated landfall in Malabar (Kerala) in 1498. Following old legends about 'Lost Christians' in the vast eastern lands of the 'Indies,' he persistently mistook the Hindus he met for Christians and made his crew pray in front of an image of a Hindu goddess which he claimed represented the Catholic Holy Mary. More than just a temporary gaffe or hermeneutical illusion, I argue, Vasco Da Gama's error emerged from complex theological and epistemological preconceptions that, for a very long time, resisted the recognition that there exist other religions besides Christianity. A most common factor in these preconceptions was no one less than the 'Devil', who was despised in contemporary sources for 'manag[ing] to ape the true God everywhere in blind paganism, simulating the mysteries of the Faith, so that, even when the truth is later proclaimed, men cannot distinguish it from the falsehoods in which they were brought up, for when one is shortsighted and things present some similarity, one thing is easily mistaken for another' (Godinho 1990: 42). 


\section{ABSTRACTS}

In the $16^{\text {th }}$ and $17^{\text {th }}$ centuries, Jesuit missionaries began to translate Christian doctrine and mythology into Indian languages. Most critical became the question how the very name(s) of God and gods can be translated. Artfully composed texts known as Christian Purānas borrowed from the religious terminology and literary styles of Indian devotional literature and are praised today for mediating between the cultures of Christians and Hindus (the latter called 'gentiles' in the contemporary sources). At the same time, the Portuguese-Catholic regime in India launched a ruthless iconoclastic campaign against the culture of the Indian gentiles, destroying their temples and images and denigrating their allegedly 'false gods.' Against this background, the article addresses the questions of what the relation was between translation and violence; how hermeneutics and destruction coexisted; and how the idea that the translations facilitated the modern emergence of religious pluralism is to be qualified.

\section{INDEX}

Keywords: translation, early modernity, Hinduism, Christianity, Jesuits, accommodatio, iconoclasm, semiotics, pluralism

\section{AUTHOR}

\section{ALEXANDER HENN}

Associate Professor, Department of Religious Studies, University of Arizona 